\title{
Random Amplified Polymorphic DNA (RAPD) Analysis of Three Japanese Aster Species
}

\author{
Yoshikazu Hoshi ${ }^{1 *}$, Tatsuro Yahata ${ }^{2}$, Hikaru Kamigomori ${ }^{2}$, and Akiko Soejima ${ }^{3}$ \\ ${ }^{1}$ Department of Plant Science, School of Agriculture, Tokai University, \\ Kawayo, Minamiaso-mura, Aso-gun, Kumamoto 869-1404, Japan \\ ${ }^{2}$ Graduate School of Agriculture, Tokai University, \\ Kawayo, Minamiaso-mura, Aso-gun, Kumamoto 869-1404, Japan \\ ${ }^{3}$ Graduate School of Science and Technology, Kumamoto University, \\ 2-39-1 Kurokami, Chuo-ku, Kumamoto 860-8555, Japan
}

Received March 4, 2013; accepted June 10, 2013

\begin{abstract}
Summary RAPD analysis was carried out using 60 random primers to investigate molecular genetic characterization of the amphidiploid Aster microcephalus var. ovatus and its presumable diploid parents. One of the presumable parents, A. iinumae, possesses S-type karyotype consisting of shorter chromosomes, which is considered to be derived from L-type karyotype consisting of longer chromosomes, characteristic to another presumable parent, $A$. ageratoides. In all, 611 reproducible fragments were amplified, and the fragment-band size range was from 50 to $12000 \mathrm{bp}$ in the three species. Cluster analysis of RAPD data showed that the three species had quite similar genetic distances from each other with high values. The karyotypes of both Aster ageratoides and A. microcephalus var. ovatus include a set of L-type chromosomes, and the two species possess about 100 specific RAPD bands in common. The common band number between A. ageratoides and A. microcephalus var. ovatus was quite higher than those between A. ageratoides and A. iinumae, and between A. iinumae and A. microcephalus var. ovatus. This indicates that many fragments found in the L-type chromosomes do not exist in the S-type chromosomes, which could have caused chromosome size reduction from L-type to S-type.
\end{abstract}

Key words Molecular characterization, RAPD, Aster, Karyotype, Cluster analysis.

Aster L. (Asteraceae) comprises about 400 species distributed widely in the northern hemisphere (Noyes and Rieseberg 1999). Due to the existence of many closely related genera (Bremer 1994), the generic circumscription of this genus has been controversial. There has also been a generic controversy over East Asian Aster. Based on morphological information of the length of the pappus, Kitamura (1937) segregated three small genera, Kalimeris Cass., Heteropappus Less., and Miyamayomena Kitamura (=Gymnaster Kitamura), from Aster s.l. However, molecular phylogenic trees drawn by subsequent works suggested that these three genera should be merged together with Aster s.l. (Ito et al. 1995, 1998). The molecular works showed multiple origins of Kalimeris and Miyamayomena derived from different ancestors of Aster, and Heteropappus also derived from Aster independently.

Previous cytogenetic studies using the Japanese genera have revealed that most species of Kalimeris had karyotypes consisting of significantly smaller chromosomes (S-type karyotype) than those of other genera (L-type karyotype) (Huziwara 1957a, b, 1958, 1967, Shindo 1967, Gu 1989). Consequently, these works indicated that the lengths of the pappus and chromosomes could have been shortened in parallel evolution.

\footnotetext{
*Corresponding author, e-mail: yhoshi@agri.u-tokai.ac.jp

DOI: $10.1508 /$ cytologia. 78.249
} 

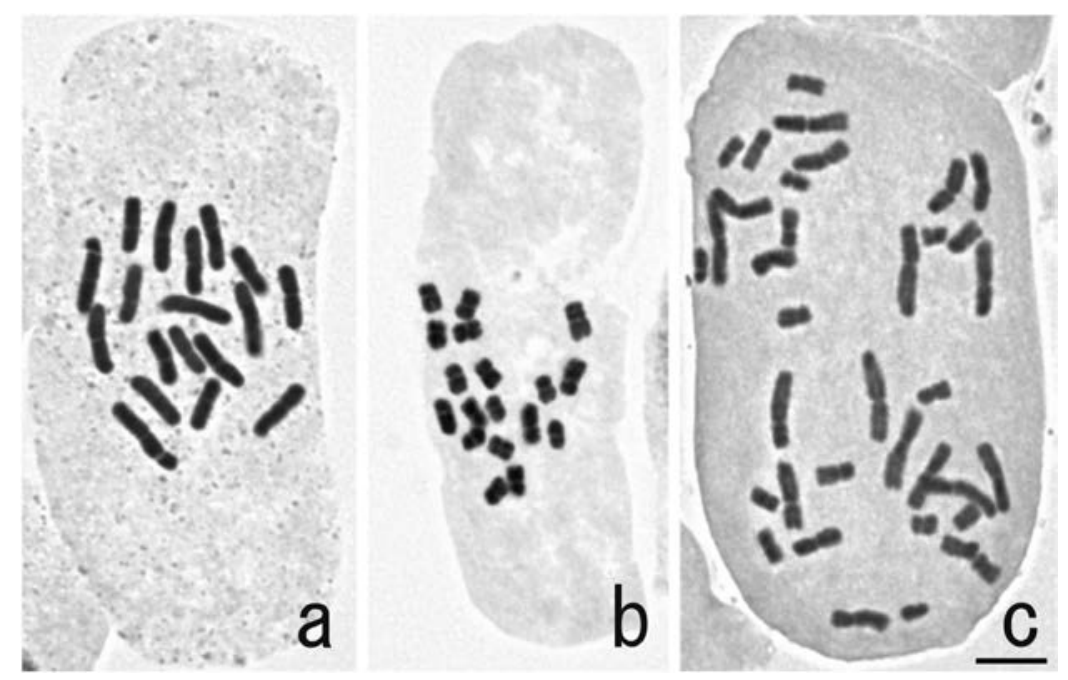

Fig. 1. Somatic chromosome complements of Aster ageratoides var. ageratoides (a), Aster iinumae (b), and Aster microcephalus var. ovatus (c). Bar $=\mathrm{X} \mu \mathrm{m}$.

Recent cytogenetic studies of Aster deal mainly with chromosome size changes and polyploidization in three species, Aster ageratoides Turcz. var. ageratoides (designated as A. leiophyllus Franch. \& Sav.), Aster iinumae Kitam. ex Hara (designated as K. pinnatifida (Matsum.) Kitam.), and A. microcephalus var. ovatus (Franch. \& Sav.) Soejima et Mot. Ito (designated as A. ovatus) (Matoba et al. 2005, 2007). Aster ageratoides has karyotypes consisting of significantly larger chromosomes (L-type karyotype) than those of $A$. iinumae (S-type karyotype) (Fig. 1). Both species are diploids. Interestingly, despite the large size difference between L- and S-type chromosome sets, their chromosome formulas are quite similar; they consist of 2 satsubmedian-, 14 median-, and 2 submedian-centromeric chromosomes (Matoba et al. 2005). Additionally, the tetraploidal LS-type karyotype, considered to be an amphidiploid between them, is found in A. microcephalus var. ovatus (Huziwara 1957b, Tara 1977, Matoba et al. 2005, 2007) (Fig. 1).

It is known that the genome size of a plant species is greatly affected by the amount of repetitive sequences and ploidy levels. The difference in the number of repetitive sequences contributes significantly to genome size, organization of chromosomes, and evolution of plant species (Bennetzen 2000). Although previous studies have indicated that Kalimeris was derived from Aster s.str. (Ito et al. 1995, 1998), there has been no attempt to search caused-DNA sequences directly connected to genome size reduction in this lineage.

The random amplified polymorphic DNA (RAPD) method of DNA amplification (Williams et al. 1990) has been widely used as a means of generating genetic markers in many organisms. The RAPD technique could identify genotypes directly and help to mitigate complications arising from earlier cytological and morphological studies (Das 2008). However, in recent molecular work on angiosperms, RAPD generated-DNA sequences were more repetitive in the genome (Koo et al. 2005), and were obtained preferrentially from a genome with karyotypes consisting of large chromosomes (Hoshi et al. 2010).

In this study, RAPD analysis was carried out using 60 random primers to investigate the molecular genetic characterization of the amphidiploid A. microcephalus var. ovatus and its parental diploid-species with different karyotypes in chromosome size. 
Table 1. Source of the materials of three species of Aster

\begin{tabular}{lccccc}
\hline \hline \multicolumn{1}{c}{ Species } & $\begin{array}{c}\text { Chromosome } \\
\text { number }(2 n)\end{array}$ & $\begin{array}{c}\text { Karyotype } \\
\text { formula }\end{array}$ & $\begin{array}{c}\text { Ploidy } \\
\text { level }\end{array}$ & $\begin{array}{c}\text { Strains } \\
\text { (source and cultivar) }\end{array}$ & Accession code \\
\hline Aster ageratoides var. ageratoides & 18 & $18 \mathrm{~L}$ & Diploid & Miyazaki Prefecture, Japan & $20080819 \# 1-2$ \\
Aster iinumae & 18 & $18 \mathrm{~S}$ & $\begin{array}{c}\text { Diploid } \\
\text { Tetraploid }\end{array}$ & $\begin{array}{c}\text { Niigata Prefecture, Japan } \\
\text { Osaka Prefecture, Japan }\end{array}$ & $\begin{array}{c}20081104 \# 02-3 \\
200906041-1\end{array}$ \\
\hline
\end{tabular}

${ }^{a}$ L: large size chromosome, S: small size chromosome (see Matoba et al. 2007)

Materials and methods

\section{Plant materials}

The plant materials of three species of Aster used are listed in Table 1. To extract total genomic DNA, leaf materials of the plants were obtained from cultivated plants. All of the plants used were cultivated in the Laboratory of Plant Environment Science, Department of Plant Science, School of Agriculture, Tokai University.

\section{DNA extraction}

The present procedure of total genomic DNA extraction is a modification of the CTAB method of Doyle and Doyle (1990). The DNAs were extracted from fresh leaves of the living plant individuals. The fresh leaves were frozen in liquid nitrogen and homogenized to a fine powder. The powdered samples were gently dispersed in an extraction buffer containing $1 \mathrm{M}$ Tris- $\mathrm{HCl}(\mathrm{pH} 8.0)$, $20 \mathrm{mM}$ EDTA, $1.4 \mathrm{M} \mathrm{NaCl}, 2 \%$ cetyltrimethylammonium bromide, and $0.5 \%$ mercaptoethanol, and were treated with the buffer for $1 \mathrm{~h}$ at $55^{\circ} \mathrm{C}$. After the treatment, they were extracted three times with an equal volume of chloroform-isoamyl alcohol $(24: 1)$ for $15 \mathrm{~min}$ each, and the DNAs were precipitated with an equal volume of isopropyl alcohol.

\section{RAPD amplification}

RAPD amplification was conducted following the instructions of the RAPD decamer Kit (Operon Technologies, Alameda, CA, USA). To optimize the polymerase chain reaction (PCR) amplification conditions, experiments were carried out with varying concentrations of DNA template, primers, and Taq DNA polymerase. Sixty primers of OPA, OPB, and OPC series were selected from the RAPD primer set of Operon Technologies (Alameda, CA, USA).

Amplification was performed on a PCR thermalcycler, Program Temp Control System (Astec, PC-708), with $20 \mu 1$ reaction mixtures containing $20 \mathrm{ng}$ of template DNA, $0.2 \mathrm{mM}$ of each dNTP (dATP, dTTP, dCTP and dGTP), 0.5 units of Taq DNA polymerase (Toyobo, TAP-211), 10 pmol of primer, $10 \mathrm{mM}$ Tris- $\mathrm{HCl}, 50 \mathrm{mM} \mathrm{KCl}$, and $1.5 \mathrm{mM} \mathrm{MgCl}_{2}$. The amplification regime was performed using the following program: $92^{\circ} \mathrm{C}$ for $3 \mathrm{~min}$ followed by 45 cycles at $92^{\circ} \mathrm{C}$ for $1 \mathrm{~min}, 40^{\circ} \mathrm{C}$ for $1 \mathrm{~min}, 72^{\circ} \mathrm{C}$ for $2 \mathrm{~min}$, and a final extension at $72^{\circ} \mathrm{C}$ for $10 \mathrm{~min}$. Amplified PCR products were performed onto an agarose gel $(1.0 \% \mathrm{w} / \mathrm{v})$ (Nacalai Tesque, Kyoto, Japan) electrophoresis (iMyrun IMR-201) in $0.5 \times$ TAE buffer at $100 \mathrm{~V}$ for $50 \mathrm{~min}$. The gel was visualized by ethidium bromide staining and photographed under a UV illuminater (Funakoshi, NTM-20).

\section{Data analysis}

All RAPD bands were repeated twice using the same reaction mixture in order to confirm the reproducible amplification of scored fragments. The bands exhibited in both repeated experiments were counted as reproducibly-amplified DNA fragments, and were scored for the construction of the data matrix. The bands that appeared at the same position as the control RAPD samples (with- 


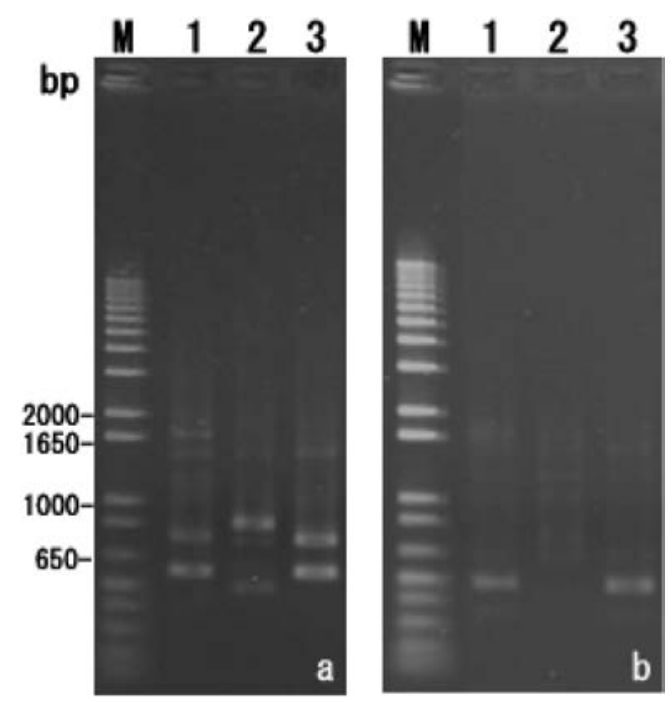

Fig. 2. RAPD products from total DNAs. Aster microcephalus var. ovatus (1), Aster iinumae (2) and Aster ageratoides var. ageratoides (3) was amplified by OPA-01 (a) and OPA-12 (b) RAPD primers. $1 \mathrm{~kb}$ Plus DNA Ladder was used for molecular marker (M).

out any template DNA) were excluded. Each band selected was scored for presence (1) or absence (0) of a band. The pooled data matrix was entered into the StatPartner version 2.0 package. A dendrogram was constructed by employing the single linkage method (Sneath, 1957) and UPGMA (unweighted pair group method with arithmetic average) (Sokal and Sneath 1963) to group individuals into discrete clusters.

\section{Results and discussion}

\section{RAPD profiling}

The stability of RAPD bands for characterizing the molecular difference within the three Aster species was well demonstrated with the purified genomic DNA (Fig. 2). A total of 60 decamer random sequences of three primer series (OPA, OPB, and OPC) were initially screened to select proper primers for RAPD analysis. All primers were examined in each of the three Aster species accessions for testing RAPD-generated banding patterns. To obtain solid data on band scoring, smear PCR products or obscure bands were removed form the pooled matrix. After the initial electrophoretic-test, 44 primers showed stables bands across all the species, and all other primers showed stable bands in either one or two species. Each primer amplified less than ten varying numbers of DNA fragments. Thus, the obtained bands with all 60 primers were used for further analysis.

In all, 611 reproducible fragments were amplified, and the fragment-band size range was from 50 to $12000 \mathrm{bp}$ in three species. The generated bands were in the range of 50 to $12000 \mathrm{bp}$ in A. ageratoides, 50 to $12000 \mathrm{bp}$ in A. iinumae, and 200 to $12000 \mathrm{bp}$ in A. microcephalus var. ovatus. The maximum number of major amplicons generated by RAPD was 13, obtained with primers OPB01 and OPC-01.

Each primer of OPB-16, OPB-19, and OPC-16 revealed a single band for each species, which is polymorphic among the three species. Ten bands were common to A. ageratoides and A. iinumae, and these bands were obtained from 10 primers. Seventy-seven common bands to $A$. ageratoides and $A$. microcephalus var. ovatus were obtained from 43 primers, while 27 common bands to A. iinumae and A. microcephalus var. ovatus were obtained from 22 primers. Ninty-seven and 51 
Table 2. Genetic distances obtained from pairwise analysis of single linkage method among various Aster species based on RAPD analysis

\begin{tabular}{lccc}
\hline \hline \multicolumn{1}{c}{ Species } & A. ageratoides var. ageratoides & A. iinumae & A. microcephalus var. ovatus \\
\hline A. ageratoides var. ageratoides & 0.00 & & \\
A. iinumae & 15.87 & 0.00 & 0.00 \\
A. microcephalus var. ovatus & 15.36 & 15.49 & \\
\hline
\end{tabular}

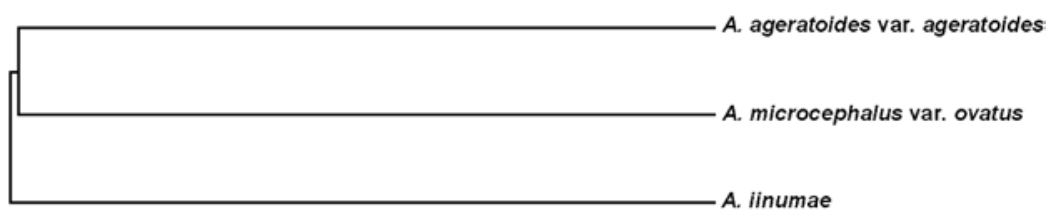

1.0

Fig. 3. Dendrogram of genetic relationships between three Aster species. The scale indicates the genetic distance derived from RAPD markers data. The cluster tree was determined with the single linkage method (Sneath 1957).

bands generated by 45 and 30 RAPD primers, respectively, were specific to A. ageratoides and A. iinumae. In contrast, 102 bands generated by 44 primers were specific to A. microcephalus var. ovatus.

Pairwise genetic distances among the three Japanese Aster species in the present study are shown in Table 2. The highest genetic distance was 15.875 with 252 character differences between $A$. ageratoides and $A$. iinumae, while the lowest genetic distance was 15.362 with 236 character differences between $A$. ageratoides and $A$. microcephalus var. ovatus. The genetic distance between A. iinumae and A. microcephalus var. ovatus showed an intermediate value of 15.492 with 240 character differences. Cluster analysis of the genetic distance values was performed to generate a dendrogram showing overall genetic relatedness among these three species (Fig. 3). The cluster tree showed that each species had almost the same branch length, although the first cluster comprised A. ageratoides and A. microcephalus var. ovatus, and Aster iinumae formed the next higher genetic distance cluster (Fig. 3).

The present RAPD result showed that the three species of Japanese Aster have quite similar genetic distances from each other with high values. This indicates that these species kept a high degree of genetic differentiation, which might be caused by a lot of fragments unique to each species. However, the common band number between A. ageratoides and A. microcephalus var. ovatus was higher than that between $A$. ageratoides and $A$. iinumae, and between $A$. iinumae and A. microcephalus var. ovatus. This indicates that the species with the L-type chromosomes shares many fragments that the S-type chromosomes lack. Current molecular work on Drosera suggested that the DNA fragments obtained by RAPD primers were preferentially amplified from the species containing a common genome consisting of large chromosomes (Hoshi et al. 2010). This amplifying preference led us to predict that RAPD-generated DNA fragments possessed many of the DNA sequences related to chromosome size changes.

For the three speceis in this study, A. microcephalus var. ovatus with the LS-type karyotype is considered to be an amphidiploid derived from hybridization between $A$. ageratoides with the L-type karyotype and A. iinumae with the S-type karyotype (Ito et al. 1995, 1998, Matoba et al. 2005, 2007). The S-type karyotype is suggested to be derived from the L-type karyotype by chromosome size changes (Ito et al. 1995 1998). In our comparison of RAPD bands among the three species, the fragments shared by the species with the L-type and LS-type karyotypes, but not found in the S-type might be related to chromosome size reduction from L-type to S-type. The existence 
of fragments specific to each species could be explained by their possible occurence or disappearance after chromosome size changes or after establishing the LS-type karyotype by amphidiploidization events.

Further molecular analyses, including FISH, are necessary to find the causal sequences related to chromosome evolution with Aster species differentiation.

\section{Acknowledgements}

This study was financially supported by the Ministry of Education, Culture, Sports, Science and Technology of Japan, Grant-in-Aid for Scientific Research (C), 2010-2012, 22570097.

\section{References}

Bennetzen, J. L. 2000. Transposable element contributions to plant gene and genome evolution. Plant Mol. Biol. 42: 251269.

Bremer, K. 1994. Asteraceae. Cladistics and classification. Timber, Portland.

Das, A. B. 2008. Assessment of genetic diversity and phylogenetic analysis of 'Star Cactus' (Astrophytum) through chromosome and RAPD markers. Cytologia 73: 179-188.

Doyle, J. J., and Doyle, J. L. 1990. A rapid total DNA preparation procedure for fresh plant tissue. Focus 12: 13-15.

Gu, H. Y. 1989. On chromosome numbers of Kalimeris (Astereae, Asteraceae) and some related taxa. Cathaya 1: 1-16.

Hoshi, Y., Kondo, K., Takeo, M., and Nagano, K. 2010. A molecular genetics of Drosera spatulata complex by using of RAPD analysis. Chromosome Bot. 5: 23-26.

Huziwara, Y. 1957a. Karyotype analysis in some genera of Compositae. II. The karyotype of Japanese Aster species. Cytologia 22: 96-112.

Huziwara, Y. 1957b. Karyotype analysis in some genera of Compositae. III. The karyotype of the Aster ageratoides group. Am. J. Bot. 44: 783-790.

Huziwara, Y. 1958. Karyotype analysis in some genera of Compositae. IV. The karyotypes within the genera Gymnaster, Kalimeris and Heteropappus. Cytologia 23: 33-45.

Huziwara, Y. 1967. Chromosomal evolution in Aster and related genera. Taxon 16: 303-304.

Ito, M., Soejima, A., Hasebe, M., and Watanabe, K. 1995. A chloroplast-DNA phylogeny of Kalimeris and Aster, with reference to generic circumscription. J. Plant Res. 108: 93-96.

Ito, M., Soejima, A., and Watanabe, K. 1998. Phylogenetic relationships of Japanese Aster (Asteraceae, Astereae) sensu lato based on chloroplast-DNA restriction site mutations. J. Plant Res. 111: 217-223.

Kitamura, S. 1937. Compositae Japonicae. I. Mem. Coll. Sci. Kyoto Imp. Univ., Ser. B, Biol. 13: 337-357.

Koo, D. H., Choi, H. W., Cho, J., Hur, Y., and Bang, J. W. 2005. A high-resolution karyotype of cucumber (Cucumis sativus L. 'Winter Long') revealed by C-banding, pachytene analysis, and RAPD-aided fluorescence in situ hybridization. Genome 48: 534-540.

Matoba, H., Soejima, A., and Hoshi, Y. 2007. Identification of parental genomes and genomic organization in Aster microcephalus var. ovatus. J. Plant Res. 120: 585-593.

Matoba, H., Soejima, A., Hoshi, Y., and Kondo, K. 2005. Molecular cytogenetic organization of 5S and 18S rDNA loci in Aster ageratoides var. ageratoides, A. iinumae (=Kalimeris pinnatifida) and A. microcephalus var. ovatus in Japan. Cytologia 70: 323-330.

Noyes, D., and Rieseberg, L. H. 1999. ITS sequence data support a single origin for North American Astereae (Asteraceae) and reflect deep geographic divisions in Aster s.1. Am. J. Bot. 83: 398-412.

Shindo, K. 1967. Cytological, morphological and geographical studies on the differentiation of species in section Asteromoea of Kalimeris in Japan. J. Sci. Hiroshima Univ., Ser. B, Div. 2, 11: 127-199.

Sneath, P. H. A. 1957. The application of computers to taxonomy. J. Gen. Microbiol. 17: 201-226.

Sokal, R. R., and Sneath, P. H. A. 1963. Principles of Numeric Taxonomy. Freeman, San Francisco. p. 359.

Tara, M. 1977. Cytologenetic studies on natural intergeneric hybridization on Aster alliances. IV. Experimental confirmation of the hybrid origin of Aster ageratoides subsp. ovatus. Bot. Mag. Tokyo 90: 253-258.

Williams, J. G. K., Kublick, A. R., Livak, K. J., Rafalsky, J., and Tingey, S. V. 1990. DNA polymorphism amplified by arbitrary primers are useful as genetic markers. Nucleic Acids Res. 18: 6531-6535. 